\title{
HOSPITALIZATIONS FOR AMBULATORY CARE SENSITIVE NONCOMMUNICABLE DISEASES OF THE CIRCULATORY SYSTEM
}

\author{
José Marcel Mello ${ }^{1}$, Pollyanna Kássia de Oliveira Borges², Erildo Vicente Muller³, Clóris Regina Blanski Grden", \\ Fabiane Karine Pinheiro ${ }^{5}$, Wesley Sousa Borges ${ }^{6}$
}

\footnotetext{
${ }^{1}$ Specialist in Mental Health and Psychosocial Care. RN, Hospital Regional dos Campos Gerais. Ponta Grossa, Paraná, Brazil. E-mail: josemarcelmello@gmail.com

2 Ph.D. in Public Health. Professor, Departamento de Enfermageme Saúde Pública, Universidade Estadual de Ponta Grossa (UEPG). Ponta Grossa, Paraná, Brazil. E-mail: pollyannakassia@hotmail.com

${ }^{3}$ Ph.D. in Public Health. Professor, Departamento de Enfermagem e Saúde Pública, UEPG. Ponta Grossa, Paraná, Brazil. E-mail: erildomuller@hotmail.com

${ }^{4}$ Ph.D. in Nursing, Professor, UEPG. Ponta Grossa, Paraná, Brazil. E-mail: reginablanski@hotmail.com

${ }^{5}$ Specialist in Public Health. Professor, UEPG. Ponta Grossa, Paraná, Brazil. E-mail: fabianekp@ig.com.br

${ }^{6}$ M.Sc. in Clinical Analysis. Professor, Colégio Adventista do Portão. Curitiba, Paraná, Brazil. E-mail: professorwesleyborges@hotmail.com
}

\begin{abstract}
Objective: describe hospitalizations for ambulatory care sensitive chronic conditions in the state of Paraná, Brazil from 2000 to 2011

Method: epidemiological ecological study was to. After descriptive analysis of the data, hospitalization indicators were developed to describe the results.

Results: this study's findings suggest that efforts to implement and expand Primary Health Care in Paraná in the last decade resulted in a decrease in the proportion of hospitalizations for ambulatory care sensitive conditions and the average number of hospitalizations for noncommunicable chronic diseases, though the ratio of hospitalizations to resident population has increased.

Conclusion: attention should be specifically paid to certain causes of hospitalization, such as hypertension and diabetes mellitus, to further minimize hospitalizations for Cerebrovascular Diseases and Congestive Heart Failure, which remained high.

DESCRIPTORS: Hospitalizations. Hospital statistics. Hospital information system. Primary health care. Chronic disease.

\section{INTERNAÇÕES POR DOENÇAS CRÔNICAS NÃO TRANSMISSÍVEIS DO SISTEMA CIRCULATÓRIO, SENSÍVEIS À ATENÇÃO PRIMÁRIA À SAÚDE}

\section{RESUMO}

Objetivo: descrever as internações por doenças crônicas não transmissíveis, sensíveis à Atenção Primária à Saúde, no Estado do Paraná, no período de 2000 a 2011.

Método: estudo epidemiológico, do tipo ecológico. Após análise descritiva dos dados, foram elaborados indicadores de internações para descrever os achados da pesquisa.

Resultados: os esforços para implantação e ampliação da Atenção Primária à Saúde no Paraná, na última década, têm refletido na redução da proporção das internações por causas sensíveis à atenção primária e no número médio de internações por doenças crônicas não transmissíveis. Porém, a razão de internações sofreu um crescimento.

Conclusão: determinadas causas de internações como a hipertensão e diabetes mellitus devem ser olhadas especificamente na Atenção Primária à Saúde, a fim de minimizar ainda mais as internações por doenças cerebrovasculares e insuficiência cardíaca congestiva, que se mantiveram elevadas.

DESCRITORES: Hospitalização. Estatísticas hospitalares. Sistema de informação hospitalar. Atenção primária à saúde. Doença crônica. 


\section{LAS HOSPITALIZACIÓNES POR ENFERMEDADES CRÓNICAS NO TRANSMISIBLES DEL SISTEMA CIRCULATORIO, SENSIBLES A LA ATENCIÓN PRIMARIA A LA SALUD}

\section{RESUMEN}

Objetivo: describir las hospitalizaciones por enfermedades crónicas no transmisibles, sensibles a la Atención Primaria en Salud en el Estado del Paraná, en el período de 2000 a 2011.

Método: Estudio epidemiológico, de tipo ecológico. Después de un análisis descriptivo de los resultados, se desarrollaron indicadores de las admisiones para describir los hallazgos de la investigación

Resultados: los esfuerzos para la implementación y expansión de la Atención Primaria de Salud en Paraná en la última década se han reflejado en la reducción de la proporción de hospitalizaciones por causas sensibles a la atención primaria y en el promedio de ingresos por enfermedades crónicas no transmisibles. Sin embargo, la proporción de hospitalizaciones sufrió un crecimiento.

Conclusión: determinadas causas de hospitalizaciones, como la hipertensión y la diabetes mellitus, deben ser consideradas específicamente en la Atención Primaria de la Salud, con el fin de minimizar aún más las hospitalizaciones por Enfermedades Cerebrovasculares y la Insuficiencia Cardíaca Congestiva que permanecieron en alta.

DESCRIPTORES: Hospitalización. Estadísticas hospitalares. Sistema de información hospitalar. Atención primaria a la salud. Enfermedad crónica.

\section{INTRODUCTION}

Ambulatory care sensitive conditions (ACSC) represent a group of health problems for which the effective action of primary care health can decrease the risk of hospitalization..$^{1-2}$ These conditions are listed per groups of causes for hospitalizations and diagnoses according to the International Classification of Diseases $-10^{\text {th }}$ Revision (ICD-10). This list is used as an instrument to assess primary health care (PHC) or the use of hospital care. ${ }^{3}$

Noncommunicable diseases (NCD) are currently considered to be severe public health problems and, according to the World Health Organization (WHO), ${ }^{4-5}$ account for $58.5 \%$ of deaths and $45.9 \%$ of the disease burden in the world. In recent decades. NCD were in the causal structure of most deaths and cases of impairment in Brazil, exceeding mortality caused by infectious and parasitic diseases, accounting for a large portion of expenses from hospital care provided by the Brazilian public health system (SUS) and in the private sector. ${ }^{6}$

The $\mathrm{WHO}^{5}$ defines cerebrovascular, cardiovascular and renovascular diseases, cancer, respiratory diseases, and diabetes mellitus (DM) as NCD. All these conditions require continued care and effort from a large number of devices, public policies and people, in general.

Following a worldwide trend, $72 \%$ of the deaths in Brazil and 75\% of expenses from care provided by the SUS stem from NCD. This shows a change in the burden of diseases and represents a new challenge for health managers, given the strong impact on the quality of life of those affected by NCD, the strong likelihood of early death, and adverse economic effects on families, communities and society, in general. ${ }^{7}$

Given the previous discussion, this study's objective was to identify the frequency and distribution of hospitalizations for ACSC between 2000 and 2011 in the state of Paraná, Brazil related to arterial hypertension $(\mathrm{AH}), \mathrm{DM}$, cerebrovascular diseases (CD) and congestive heart failure (CHF), in order to indirectly verify the care provided by $\mathrm{PHC}$ to affected individuals.

\section{METHOD}

This epidemiological, ecological, times series, descriptive study addressed hospitalizations for ACSC between 2000 and 2011 in the state of Paraná, Brazil according to cause: AH, DM, CD, and $\mathrm{CHF}$. An ecological study is one in which the unit of observation is a group of people rather than an individual; groups can be cities, states, countries or other entities. ${ }^{8}$ In this study, the units of observation were health regions to facilitate the visualization of different aspects related to access to health services in the state.

The period under study was divided into three-year periods: the first (2000-2002), second (2003-2005), third (2006-2008), and fourth threeyear period (2009-2011). In 2013, public data were collected online from the Hospital Information System and TABNET ${ }^{*}$ from the SUS' Informatics Department. The absolute number of hospitalizations in the health regions of Paraná was collected

* TABNET is a tabulator that enables the organization of epidemiological data, vital statistics and other according to geographical coverage, time period, or other variables. 
along with sex and causes listed on the ICD-10, concerning the three-year periods. In 2010, the Institutional Review Board at the Universidade Estadual de Ponta Grossa approved this study (protocol 14375/2010, report No. 144/2010).

Ministerial Decree No. 221, from April 17 th 2008, which defines ACSC, was used to select the diseases. Four NCD linked to the circulatory system (CD, AH, CHF and DM) were chosen, due to their current epidemiological relevance in Brazil. The diseases were grouped as: $\mathrm{AH}$ (essential hypertension + other hypertensive diseases); $\mathrm{DM}$; $\mathrm{CHF}$; $\mathrm{CD}$ (intracranial hemorrhage, cerebral infarction, unspecified, hemorrhagic or ischemic stroke); and other cerebrovascular diseases.

Data were tabulated and descriptively analyzed (absolute frequency, mean, standard deviation, and maximum and minimum values) in Stata, version 12.0. Two indicators of hospitalizations were developed to describe the results: 1) Proportion of hospitalizations for ACSC (hospitalizations for ACSC/Total hospitalizations $x$ 100); 2) Ratio of Hospitalizations (Total Hospitalizations for ACSC in a three-year period/average population living in a health region in a three-year period $\times 10,000)$.

\section{RESULTS}

A total of 5,219,427 hospitalizations took place from 2000 to 2011 in the state of Paraná. The four main NCS (AH, DM, CD and CHF) together account for 691,253 hospitalizations in the same period, that is, $13 \%$ of all hospitalizations. A total of 103,321 hospitalizations that occurred in the period under study were caused by $\mathrm{AH}$, while
91,582, 343,005, and 153,345 hospitalizations were due to DM, CHF and CD, respectively.

When the frequency of hospitalizations was analyzed according to sex, we verified that hospitalizations caused by most diseases were more frequent among women than among men $\mathrm{AH}$ : $60.88 \%$ vs. $39.12 \%$; DM: $61.88 \%$ vs. $38.12 \%$; CHF: $52.90 \%$ vs. $47.10 \%)$.

Hospitalizations due to other causes were also more frequent among women, 2,795,821 vs. $2,423,606$ among men (53.56\% vs. $46.43 \%)$, except for hospitalizations caused by CD, the frequency of which was higher among men (45.98\% vs. $54.02 \%)$.

When the average number (Table 1) of hospitalizations for chronic diseases was calculated according to three-year periods and sex, a decrease in the average number of hospitalizations caused by $\mathrm{AH}$ and $\mathrm{CHF}$ was observed for both sexes [ $(\mathrm{AH}$ - women: $796.77(\mathrm{SD}=855.06)$ between 2000 and 2002 vs. 567.81(SD=357.64) between 2009 and 2011; men: $463.36(S D=447.67)$ in 2000-2002 and $373.54(S D=237.68)$ in 20092011); (CHF- women: $2,576.63(S D=2,119.48)$ in 2000-2002 vs. 1,710.27 (SD=1,350.09) in 20092011; men: $2,261.5(S D=1,853.46)$ in $2000-2002$ vs. $1,533.68(\mathrm{SD}=1,164.01)$ in $2009-2011)]$, though women still presented the highest average in the entire period under study. The average number of hospitalizations caused by CD fluctuated through the four three-year periods and was higher among men. The average number of hospitalizations caused by DM increased both among men and women, though women were still more frequently hospitalized due to DM in the four periods when compared to men.

Table 1 - Mean, minimum and maximum values of hospitalizations caused by ambulatory care sensitive noncommunicable diseases according to the three-year periods and sex. Paraná, Brazil, 2000-2011

\begin{tabular}{|c|c|c|c|c|c|}
\hline $\begin{array}{c}\text { Ambulatory } \\
\text { Care Sensitive } \\
\text { Condition }\end{array}$ & Sex & $\begin{array}{c}\text { Thee-year } \\
\text { period }\end{array}$ & $\begin{array}{c}\text { Mean } \\
\text { (Standard-deviation) }\end{array}$ & $\begin{array}{c}\text { Minimum of } \\
\text { hospitalizations }\end{array}$ & $\begin{array}{c}\text { Maximum of } \\
\text { hospitalizations }\end{array}$ \\
\hline \multirow{8}{*}{$\begin{array}{c}\text { Arterial } \\
\text { hypertension }\end{array}$} & \multirow{5}{*}{ Female } & $2000-2002$ & $796.77(855.06)$ & 246 & 4355 \\
\hline & & $2003-2005$ & $779.00(534.57)$ & 198 & 2437 \\
\hline & & $2006-2008$ & $715.59(448.58)$ & 225 & 2104 \\
\hline & & $2009-2011$ & $567.81(357.64)$ & 158 & 1752 \\
\hline & & $2000-2002$ & $463.36(447.67)$ & 135 & 2193 \\
\hline & \multirow{3}{*}{ Male } & $2003-2005$ & $505.13(373.90)$ & 97 & 1502 \\
\hline & & $2006-2008$ & 495.18(349.37) & 149 & 1620 \\
\hline & & $2009-2011$ & $373.54(237.68)$ & 138 & 1122 \\
\hline
\end{tabular}




\begin{tabular}{|c|c|c|c|c|c|}
\hline \multirow{8}{*}{ Diabetes mellitus } & \multirow{4}{*}{ Female } & $2000-2002$ & $624.09(726.26)$ & 157 & 432 \\
\hline & & $2003-2005$ & $574.68(457.64)$ & 174 & 2277 \\
\hline & & $2006-2008$ & 634.68(399.15) & 191 & 2002 \\
\hline & & $2009-2011$ & $742.09(473.79)$ & 221 & 2429 \\
\hline & \multirow{4}{*}{ Male } & $2000-2002$ & $348.95(422.43)$ & 66 & 2108 \\
\hline & & $2003-2005$ & $336.36(303.11)$ & 82 & 1447 \\
\hline & & $2006-2008$ & $401.81(314.50)$ & 95 & 1534 \\
\hline & & $2009-2011$ & $500.13(345.44)$ & 178 & 1735 \\
\hline \multirow{8}{*}{ Heart failure } & \multirow{4}{*}{ Female } & $2000-2002$ & $2576.63(2119.48)$ & 613 & 10596 \\
\hline & & $2003-2005$ & 2158.18(1809.75) & 457 & 9032 \\
\hline & & $2006-2008$ & $1802.22(1407.00)$ & 410 & 410 \\
\hline & & $2009-2011$ & $1710.27(1350.09)$ & 403 & 7029 \\
\hline & \multirow{4}{*}{ Male } & $2000-2002$ & $2261.5(1853.46)$ & 458 & 9272 \\
\hline & & $2003-2005$ & 1936.13(1664.87) & 368 & 8369 \\
\hline & & $2006-2008$ & 1612.5(1291.49) & 296 & 6660 \\
\hline & & $2009-2011$ & $1533.68(1164.01)$ & 326 & 6098 \\
\hline \multirow{8}{*}{$\begin{array}{l}\text { Cerebrovascular } \\
\text { diseases }\end{array}$} & \multirow{5}{*}{ Female } & $2000-2002$ & $773.40(846.45)$ & 164 & 4435 \\
\hline & & $2003-2005$ & $903.59(816.40)$ & 257 & 4255 \\
\hline & & $2006-2008$ & $742.50(753.78)$ & 237 & 3910 \\
\hline & & $2009-2011$ & 785.18(777.16) & 194 & 4004 \\
\hline & & $2000-2002$ & 908.90(987.56) & 209 & 5139 \\
\hline & \multirow{3}{*}{ Male } & $2003-2005$ & $1082.40(953.98)$ & 362 & 4999 \\
\hline & & $2006-2008$ & $875.59(846.10)$ & 313 & 4383 \\
\hline & & $2009-2011$ & $898.63(886.09)$ & 251 & 4558 \\
\hline
\end{tabular}

Analysis of the ratio between hospitalizations for ACSC and the population living in each territory of the 22 health regions of the state of Paraná revealed a decrease in the ratio of hospitalizations for $\mathrm{AH}$ in all the health regions, except for Cianorte, Paranavaí, Cornélio Procópio, Toledo and Ivaiporã, regions, which presented increased ratios. The metropolitan region was the one presenting the greatest decrease in the ratio between hospitalizations for $\mathrm{AH}$ and the resident population.

The ratio of hospitalizations for DM (Table 2) shows that all the health regions presented an increased number of hospitalizations, except for Paranaguá and Foz do Iguaçu, the ratios of which remained stable, and the metropolitan region and Londrina, which presented decreased ratios. Considering hospitalizations for CHF, Table 2 shows that the health regions presented a decreased ratio of hospitalizations, except for Telêmaco Borba and Ivaiporã, which presented an increased ratio for this disease group. The Umuarama region presented the greatest decrease, though the incidence of hospital- izations for $\mathrm{CHF}$ was still higher than those caused by other diseases.

Finally, 13 regions presented a decreased number of hospitalizations for CD; Foz do Iguaçu stood out with the lowest ratio between hospitalizations and the resident population. Nine of the regions presented an increased number of hospitalizations; Apucarana, União da Vitória and Telêmaco Borba presented the highest increase in hospitalizations in the final period.

Considering the proportion of hospitalizations for $\mathrm{AH}$ compared to the total number of hospitalizations per three-year period and region, a decrease was observed in 2000-2011 in all the health regions except Cianorte, Cornélio Procópio and Toledo. The 2003-2005 period presented the highest proportion of hospitalizations for $\mathrm{AH}$ for 14 regions. Only the metropolitan region and Londrina presented a proportion of hospitalizations for $\mathrm{AH}$ less than $1 \%$, a result found only in the last three-year period (2009-2011). 
Table 2 - Number of hospitalizations for ambulatory care sensitive conditions in the population residing in the health regions $(x 10,000 \text { people })^{*}$, according to diabetes mellitus or congestive heart failure, in the three-year periods. Paraná, Brazil, 2000-2011

\begin{tabular}{|c|c|c|c|c|c|c|}
\hline \multirow[b]{2}{*}{ Cause } & \multirow[b]{2}{*}{ Health region } & $1^{\text {st }}$ period & $2^{\text {nd }}$ period & $3^{\text {rd }}$ period & $4^{\text {th }}$ period & \multirow{2}{*}{$\begin{array}{c}\text { Difference } \\
\text { between } 1^{\text {st }} \\
\text { and } 4^{\text {th }} \text { period } \\
\text { periods }\end{array}$} \\
\hline & & $2000 / 2002$ & $2003 / 2005$ & $2006 / 2008$ & $2009 / 2011$ & \\
\hline \multirow{22}{*}{ 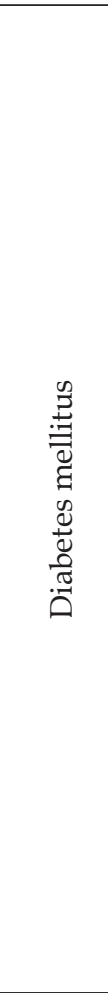 } & Paranaguá & 26.68 & 2053 & 25.28 & 26.58 & 0.1 \\
\hline & Metropolitan region & 19.96 & 11.96 & 10.60 & 12.70 & 7.26 \\
\hline & Ponta Grossa & 27.55 & 22.93 & 22.52 & 30.60 & -3.05 \\
\hline & Irati & 22.55 & 16.69 & 23.88 & 36.20 & -13.65 \\
\hline & Guarapuava & 22.93 & 20.50 & 26.88 & 37.62 & -14.69 \\
\hline & União da Vitória & 17.13 & 20.54 & 17.03 & 27.31 & -10.18 \\
\hline & Pato Branco & 18.30 & 19.28 & 25.71 & 33.56 & -15.26 \\
\hline & Francisco Beltrão & 19.23 & 21.29 & 25.68 & 29.52 & -10.29 \\
\hline & Foz do Iguaçu & 11.63 & 11.35 & 12.16 & 10.81 & 0.82 \\
\hline & Cascavel & 10.43 & 9.27 & 14.21 & 17.17 & -6.74 \\
\hline & Campo Mourão & 21.63 & 30.39 & 46.00 & 47.20 & -25.57 \\
\hline & Umuarama & 26.16 & 35.76 & 33.36 & 33.77 & -7.61 \\
\hline & Cianorte & 20.81 & 34.43 & 49.83 & 43.67 & -22.86 \\
\hline & Paranavaí & 23.65 & 29.60 & 31.67 & 48.67 & -25.02 \\
\hline & Maringá & 23.77 & 28.14 & 30.86 & 31.31 & -7.54 \\
\hline & Apucarana & 35.71 & 33.31 & 28.22 & 39.72 & -4.01 \\
\hline & Londrina & 20.22 & 19.17 & 14.77 & 15.51 & 4.71 \\
\hline & Cornélio Procópio & 49.64 & 47.73 & 51.97 & 59.17 & -9.53 \\
\hline & Jacarezinho & 34.34 & 32.78 & 44.71 & 55.98 & -21.64 \\
\hline & Toledo & 22.46 & 21.90 & 34.59 & 33.53 & -11.07 \\
\hline & Telêmaco Borba & 23.54 & 18.03 & 25.17 & 39.54 & -16.00 \\
\hline & Ivaiporã & 14.82 & 22.90 & 34.71 & 42.95 & -28.13 \\
\hline \multirow{22}{*}{ 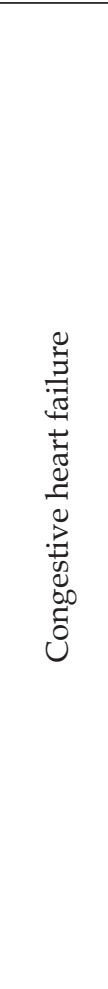 } & Paranaguá & 71.34 & 64.36 & 44.55 & 40.82 & 30.52 \\
\hline & Metropolitan region & 68.81 & 55.89 & 40.81 & 40.03 & 28.78 \\
\hline & Ponta Grossa & 75.16 & 61.90 & 56.28 & 60.19 & 14.97 \\
\hline & Irati & 71.44 & 53.77 & 44.60 & 45.11 & 26.33 \\
\hline & Guarapuava & 129.75 & 84.05 & 78.04 & 91.11 & 38.64 \\
\hline & União da Vitória & 132.06 & 109.30 & 89.35 & 76.44 & 55.62 \\
\hline & Pato Branco & 104.02 & 91.39 & 83.80 & 69.91 & 34.11 \\
\hline & Francisco Beltrão & 141.36 & 114.13 & 88.86 & 95,07 & 46.29 \\
\hline & Foz do Iguaçu & 36.28 & 40.22 & 27.82 & 32,37 & 3.91 \\
\hline & Cascavel & 144.13 & 120.13 & 75.03 & 68.23 & 75.9 \\
\hline & Campo Mourão & 212.72 & 179.43 & 145.17 & 115.43 & 97.29 \\
\hline & Umuarama & 204.72 & 149.27 & 102.53 & 97.91 & 106.81 \\
\hline & Cianorte & 140.73 & 112.50 & 105.48 & 74.40 & 66.33 \\
\hline & Paranavaí & 146.34 & 100.49 & 65.54 & 73.18 & 73.16 \\
\hline & Maringá & 143.44 & 127.17 & 82.02 & 67.70 & 75.74 \\
\hline & Apucarana & 142.78 & 109.09 & 74.90 & 65.61 & 77.17 \\
\hline & Londrina & 75.27 & 51.01 & 43.46 & 41.85 & 33.42 \\
\hline & Cornélio Procópio & 153.59 & 143.15 & 131.19 & 147.15 & 6.44 \\
\hline & Jacarezinho & 180.81 & 145.88 & 123.93 & 115.97 & 64.84 \\
\hline & Toledo & 173.37 & 134.63 & 133.37 & 118.11 & 55.26 \\
\hline & Telêmaco Borba & 175.52 & 287.11 & 345.67 & 216.78 & -41.26 \\
\hline & Ivaiporã & 152.66 & 120.11 & 164.71 & 203.02 & -50.36 \\
\hline
\end{tabular}

*Sum of hospitalizations in the period (cause)/average resident population in the health region in the period. 
The proportion of hospitalizations for DM in the total number of hospitalizations per period and region was high in the first period in Paranaguá, Ponta Grossa, and the metropolitan region (>30\%). There was a decrease in hospitalizations for DM in the second period, which remained below 5\% in the three regions aforementioned, all of which presented a high proportion in the first period. The number of hospitalizations fluctuated in the entire 2000-2011 period, except in Foz do Iguaçu and Londrina, which presented a decrease in the proportion of hospitalizations for DM in the last three-year period; hospitalizations for DM increased in the remaining regions.

Hospitalizations for CHF decreased in the period under study, except in the Telêmaco Borba and Ivaiporã regions. Telêmaco Borba presented a proportional increase greater than $22 \%$ in the third period, compared to the Foz do Iguaçu region, which presented the lowest proportion of hospitalizations for CHF in the same period; below $4 \%$ (Figure 1).

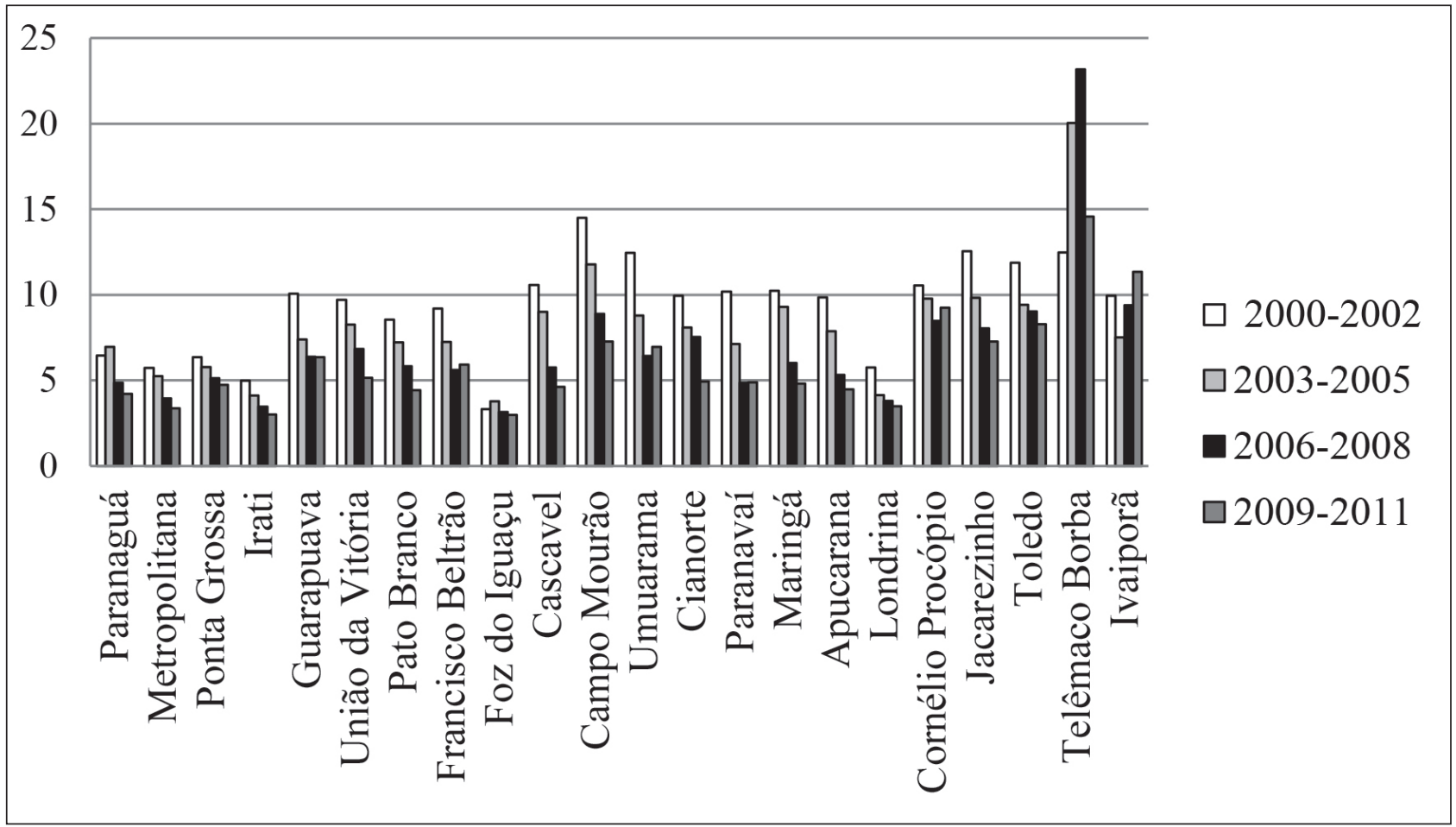

*Number of hospitalizations for ambulatory care sensitive conditions, congestive heart failure/total of hospitalizations caused by remaining diseases $\times 100$

Figure 1 - Proportion* of hospitalizations caused by ambulatory care sensitive conditions, congestive heart failure, according to health region and three-year periods. Paraná, Brazil, 2000-2011

Concluding the analysis of proportions, hospitalizations for $\mathrm{CD}$ decreased in 12 of the 22 regions. Foz do Iguaçu presented the lowest proportion of hospitalizations for CD $(<1.5 \%)$. Eight regions presented an increase in the number of hospitaliza- tions for $\mathrm{CD}$, while União da Vitória, Apucarana and Telêmaco Borba presented a large increase in the proportion of hospitalizations in comparison to the remaining regions for the period under analysis (Figure 2). 


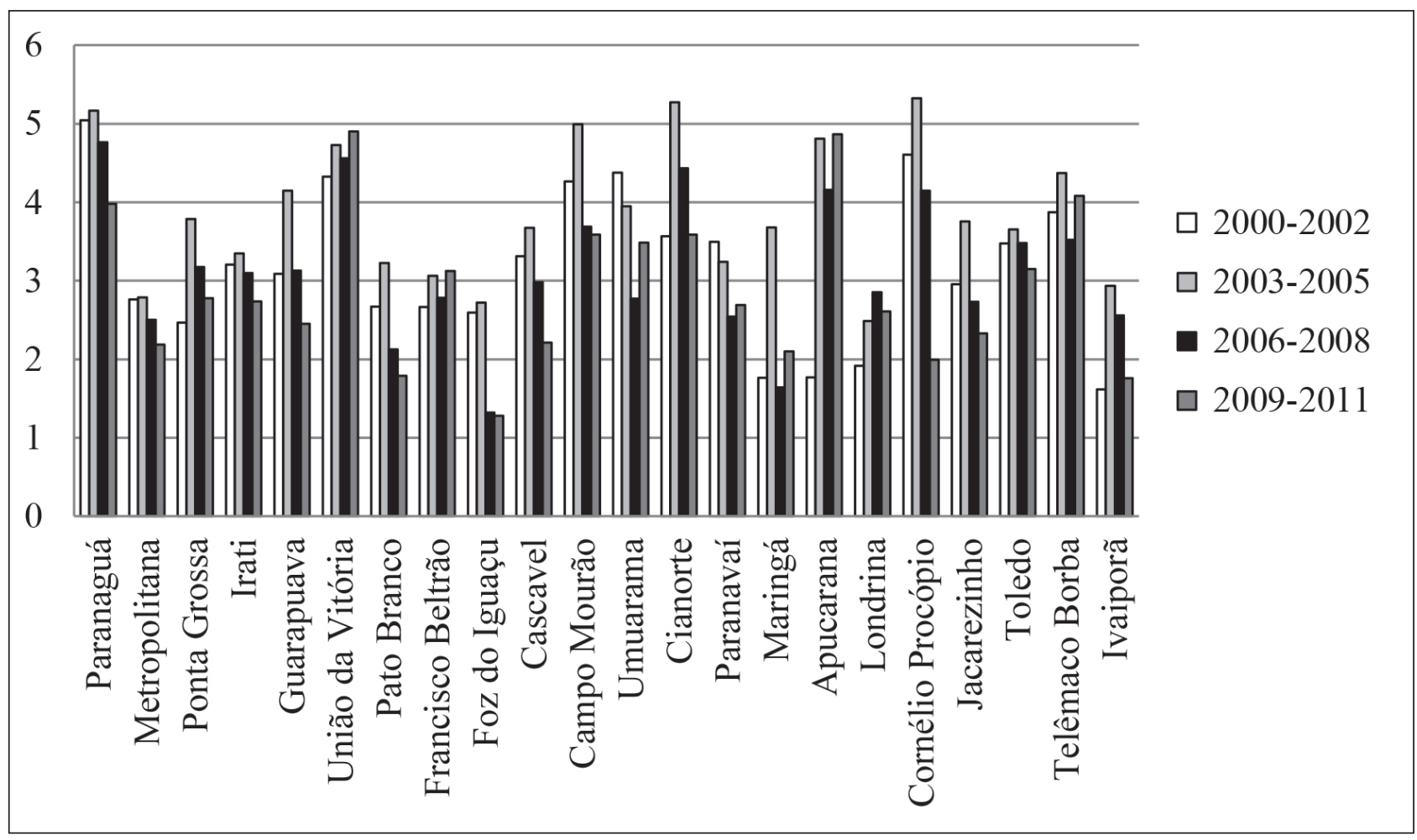

*Number of hospitalizations for ACSC, cerebrovascular diseases/total hospitalizations for all remaining diseases x100.

Figure 2 - Proportion* of hospitalizations for ambulatory care sensitive conditions, cerebrovascular diseases per region and three-year period. Paraná, Brazil, 2000-2011

\section{DISCUSSION}

Hospitalizations for ACSC reflect the lifestyle adopted by the population, as well as the level of access to and quality of PHC services. The NCD epidemic strongly impacts human and social development. The four NCD addressed in this study account for $13 \%$ of all hospitalizations observed in the period, confirming the findings of one study ${ }^{9}$ conducted in one region of the state of São Paulo, in which CHF, angina, and CD were frequent causes of hospitalizations among people over 40 years of age and accounted for $71 \%$ of the expenses from hospitalizations for ACSC. For this reason, preventive measures should be a priority in the development and investment of state public health policies, as well as in the implementation of chronic disease care networks. ${ }^{2,10}$

In agreement with the findings of other studies, ${ }^{10-12}$ this study also shows that hospitalizations were more frequent among women in the case of most of the diseases under study, except hospital- izations for $\mathrm{CD}$, which were more frequent among men. A hospital-based study, ${ }^{13}$ conducted in a city in Paraná addressing ACSC hospitalizations among women, reports that $49.42 \%$ of the hospitalizations in the study group were caused by ACSC. The main causes were diseases of the circulatory system, which accounted for $17.02 \%$ of the ACSC hospitalizations. Women hospitalized because of ACSC were older, with a lower level of education, with a prior history of hospitalizations, and had weaker bonds established with the Family Health Strategy (FHS).

Considering all age groups, this study's findings show that the incidence of $\mathrm{CD}$ is greater among men. $\mathrm{CD}$ and subtypes are currently considered diseases with great relevance in the world context. Most risk factors for CD, as well as for some cardiovascular diseases, are modifiable through specific preventive measures. The risk factors increasing the likelihood of these diseases include: smoking, dyslipidemia, hypertension, diabetes mellitus, obesity, diet and sedentariness. ${ }^{14}$ 
Men's conditions are aggravated as a consequence of entering the health system through specialized care services, as through that process, proper care is delayed, which also results in higher costs to the public health system. PHC needs to be strengthened and qualified to ensure health promotion and the prevention of avoidable diseases. Comparison between men and women shows that men are more vulnerable to diseases, especially severe and chronic diseases, dying earlier than women. Such a context has been verified by some researchers, ${ }^{15}$ who report that the magnitude of mortality caused by $\mathrm{CD}$, in the state of Paraná, was greater among men. Many diseases are avoidable through primary preventive measures but, despite men's greater vulnerability and high rates of mortality and morbidity, they do not usually seek PHC services. ${ }^{16}$ As opposed to men, women have a greater life expectancy; however, women do become sick more frequently. ${ }^{17}$ Women's vulnerability to certain diseases and causes of death is more related to the situation of discrimination in society than it is to biological factors. ${ }^{18}$ Authors ${ }^{13}$ have suggested that studies on ACSC hospitalizations should address gender issues to observe the specific conditions affecting women and men.

Another important finding of this study refers to the average number of hospitalizations caused by CHF in the state of Paraná, which presented a decrease in the last decade. Despite this decrease, $\mathrm{CHF}$ accounted for the highest average number of hospitalizations compared to the other diseases under study. CHF is a common consequence of most heart diseases and represents an important public health problem, considering its growing prevalence and the hospitalization indicators associated with high morbidity and mortality. The socioeconomic cost of this syndrome is high and involves expenditures on medications, repeated hospitalizations, loss of productivity, early retirement, surgeries, and occasionally, heart transplants. ${ }^{19}$

$\mathrm{CHF}$ is, therefore, a frequent, high-cost and often incapacitating clinical condition with a high mortality rate. A study similar to the present one assessed hospitalizations for ambulatory care sensitive noncommunicable diseases among elderly individuals in Rio Grande do Sul, Brazil. In that study, hospitalizations for CHF accounted for $12 \%$ of total hospitalizations for all causes, while hospitalizations for ACSC, that is, CHF by itself, accounted for $21.38 \%$ of hospitalizations. The frequency of hospitalizations for CHF was only lower than those caused by pulmonary diseases, though CHF presented higher hospital mortality when compared to pulmonary diseases.$^{20}$ Early diagnosis and effective treatment decrease morbidity and mortality and associated costs, justifying the importance of providing proper care to individuals with $\mathrm{CHF} .{ }^{19}$ Interventions noted in the literature to decrease hospitalizations for $\mathrm{CHF}$ and that can be applied by PHC services include regular nursing consultations along with medical and ambulatory pharmacological treatment. ${ }^{21}$

Given the previous discussion, the importance of diagnosis and intervention studies addressing individuals with NDC is stressed due to the importance of identifying the specificities of each regional context so that healthcare programs directed to these individuals are properly designed, implemented and assessed.

The Foz de Iguaçu region presented fewer ACSC hospitalizations, including all NCD under study, both in terms of proportions, ratios and averages, when compared to the other regions in the 2000-2011 period. The Telêmaco Borba and Ivaiporã regions presented a higher number of ACSC hospitalizations. There are no local studies with which to compare these findings or to help clarify the reasons of such disparities among health regions. Nonetheless, the quality of health services and the tools used to assess improvements in the quality of PHC services has been discussed. Minimum structural conditions and the composition of teams need to be considered if one wants to improve the quality of PHC units, not only in the state of Paraná, but also in the rest of Brazil, as well. ${ }^{22}$

This study's findings indicate that the quality of integral health care expected from PHC and its managers requires reconsideration of the organization of spaces, team governance, continuing education, as well as existing poor work contracts. The implementation of the FHS more than two decades ago was intended to "contribute to the reorientation of the PHC-based care model in agreement with the principles of the Unified Health System, imprinting new dynamics onto PHC units, and establishing responsibilities between health services and the population". 23:10 The Brazilian PHC was formulated to support the traditional model, to take healthcare as close as possible to families and improve the 
lives of Brazilian citizens, as a consequence. In this sense, the Ministry of Health recognized the FHS as a national strategy given its scope, impact and problem-solving capacity, as it also sought to overcome the care model existing at the time.

The state of Paraná implemented the FHS in 1998 and in November 2015, 396 of the 399 cities in Paraná had FHS teams and an estimated coverage of $67.68 \%$ of the population. ${ }^{23}$ One study addressing ACSC hospitalizations in Brazil, ${ }^{11}$ verified that in areas in which the FHS is highly active, the rates of hospitalizations for chronic diseases were 13\% lower than in areas where participation in FHS is low. This suggests that the work performed by the FHS teams has improved the performance of the Brazilian healthcare system, decreasing the number of potentially avoidable hospitalizations.

ACSC hospitalizations can be used to compare the performance of different health services, assess the effects of health policies, and assess the problem-solving capacity, quality and accessibility of PHC services. ${ }^{1}$ An ecological study ${ }^{12}$ conducted in the state of Goiás, Brazil with 221 cities verified a decrease in the average rates of hospitalizations caused by ambulatory care sensitive heart conditions between 2000 and 2008, in both sexes in towns outside of the metropolitan area with less than 50,000 inhabitants. Decreased hospitalization rates took place regardless of the FHS coverage; however, in towns with low FHS coverage, a decrease was perceived between the initial and final period of analysis, while for cities with medium and high coverage, the decrease took place between the first and third periods, as well as between the second and third periods $(\mathrm{p}<0.04)$.

When the ratio of hospitalizations was verified in the resident population, an increase in hospitalizations was observed in many health regions within the period under study. This suggests that despite the implementation of $\mathrm{PHC}$, it does not present coverage that is sufficient to the point of minimizing ACSC hospitalizations such as those caused by $\mathrm{CD}$ and CHF. Because the FHS provides care to hypertensive and diabetic patients in the HiperDia program, a lower average and proportion of hospitalizations for $\mathrm{CD}, \mathrm{CHF}, \mathrm{AH}$ and DM were expected, such as those found in this study in the last ten years. Nonetheless, when hospitalizations for these same causes are compared to the number of residents in each region, we verify that the coverage and access to FHS services should be expanded in the state of Paraná, while the quality of care delivery should also be reconsidered, as this indicator presented an increase in most of the 22 health regions.

Similar to other studies using the ACSC indicator, ${ }^{9,24}$ this study also presents limitations related to the use of secondary data, as there are no guarantees regarding the quality of information. Additionally, the literature addressing this topic diverges in terms of methodological approach, which hinders comparisons between this study's findings and those reported by other studies. Nonetheless, the results presented here contribute to the description of avoidable hospitalizations in the state of Paraná, and enable an initial assessment of state public policies implemented in the PHC sphere, suggesting that current PHC quality and accessibility are not sufficient.

\section{CONCLUSION}

This study's results indicate that the effort to implement and expand the PHC services in the state of Paraná over the last decade were reflected in a proportional decrease in ACSC hospitalizations and in the average number of NCD hospitalizations. Further studies however, are needed to encourage reflections upon the quality and accessibility to this state's PHC services, as the proportion of hospitalizations to the number of residents increased in the period under study.

Certain causes, such as hypertension and diabetes mellitus, deserve special attention in order to minimize hospitalizations caused by cerebrovascular diseases and congestive heart failure, which remain high, especially among men. Continuing education promoted among healthcare teams, as well as the use of clinical management tools such as care protocols and matrix support, can be useful to the NCD network in Paraná to continually decrease the frequency of ACSC hospitalizations.

\section{REFERENCES}

1. Alfradique ME, Bonolo PF, Dourado I, Macinko J, Mendonça CS, Oliveira VB, et al. Internações por condições sensíveis à atenção primária: a construção da lista brasileira como ferramenta para medir o desempenho do sistema de saúde (Projeto ICSAP Brasil) Cad Saúde Pública. 2009; 25(6):1337-49. 
2. Muller EV, Borges PKO, Correia ADMS, Ohata APAR, Luiz IC, Cordeiro TM. Redes de Atenção à Saúde. Ponta Grossa (PR): NUTEAD/UEPG; 2014.

3. Ministério da Saúde (MS). Portaria n. 221, 17 abril 2008: publica em forma do anexo a lista Brasileira de Internações por Condições Sensíveis à Atenção Primária. Diário Oficial da União [Internet] 2007 set 21 [cited 2013 Nov 01]; Available from: http:// bvsms.saude.gov.br/bvs/saudelegis/sas/2008/ prt0221_17_04_2008.html

4. Schmidt MI, Duncan BB, Azevedo e Silva G, Menezes AM, Monteiro CA, Barreto SM, et al. Chronic noncommunicable diseases in Brazil: burden and current challenges. Lancet [Internet]. 2011 [cited 2016 Set 28]; 377(9781):1949-61. Available from: http://www. thelancet.com/journals/lancet/article/PIIS01406736(11)60135-9/fulltext

5. World Health Organization. Joint WHO/FAO Expert Consultation on Diet, Nutrition and the Prevention of Chronic Diseases Technical Report Series, 916 [Internet]. Geneva (CH): WHO; 2003 [cited $2015 \mathrm{Jul}$ 27]. Available from: http://whqlibdoc.who.int/trs/ who_trs_916.pdf

6. Ministério da Saúde (BR). Secretaria de Vigilância à Saúde. Secretaria de Atenção à Saúde. Diretrizes e recomendações para o cuidado integral de doenças crônicas não transmissíveis: promoção da saúde, vigilância, prevenção e assistência. Brasília, 2008.

7. Ministério da Saúde (BR). Secretaria de Vigilância em Saúde. Departamento de Análise de Situação de Saúde. Plano de Ações Estratégicas para o Enfrentamento das Doenças Crônicas Não Transmissíveis (DCNT) no Brasil 2011-2022. Brasília (DF): Ministério da Saúde; 2011.

8. Haneuse S, Bartell S. Designs for the combination of group- and individual-level data. Epidemiology [Internet]. 2011 [cited 2016 Mar 28]; 22(3):382-9. Available from: http://www.ncbi.nlm.nih.gov/pmc/ articles/PMC3347777/

9. Ferreira JBB, Borges MJG, Santos LL, Forster AC. Internações por condições sensíveis à atenção primária à saúde em uma região de saúde paulista, 2008 a 2010. Epidemiol Serv Saúde [Internet]. 2014 [cited 2015 Dec 23]; 23(1):45-56. Available from: http://dx.doi. org/10.5123/S1679-49742014000100005

10. World Health Organization. Global action plan for the prevention and control of noncommunicable diseases 2013-2020 [Internet]. Geneva (CH):WHO; 2013 [cited 2016 Set 28].p.3-10; Availablefrom: http://apps.who.int/iris/ bitstream/10665/94384/1/9789241506236_eng.pdf?ua=1
11. Macinko J, Dourado I, Aquino R, Bonolo PF, LimaCosta MF, Medina MG, et al. Forte expansão da atenção básica à saúde no Brasil, associada a um declínio da hospitalização desnecessária. Health Affairs, 2010; 29(12):2149-60.

12. Batista SRR, Jardim PCBV, Sousa ALL, Salgado CM. Hospitalizações por condições cardiovasculares sensíveis à atenção primária em municípios goianos. Rev Saúde Pública [Internet]. 2012 [cited 2015 Dec 28]; 46(1):34-42. Available from: http://www. scielo.br/scielo.php?script=sci_arttext\&pid $=$ S003489102012000100005\&lng=pt

13. Pitilin ÉB, Gutubir D, Molena-Fernandes CA, Pelloso SM. Internações sensíveis à atenção primária específicas de mulheres. Ciênc Saúde Coletiva [Internet]. 2015 [cited 2015 Dec 28]; 20(2):441-8. Available from: http://dx.doi.org/10.1590/141381232015202.04482014

14. Ministério da Saúde (BR). Secretaria de Atenção à Saúde. Departamento de Atenção Básica. Prevenção clínica de doenças cardiovasculares, cerebrovasculares e renais. Brasília (DF): Ministério da Saúde; 2006.

15. Muller EV, Aranha SRR, Roza WSS, Gimeno SGA. Distribuição espacial da mortalidade por doenças cardiovasculares no Estado do Paraná, Brasil: 19891991 e 2006-2008. Cad Saúde Pública [Internet]. 2012 [cited 2015 Jul 29]; 8(6):224-30. Available from: http:/ / www.scielo.br/readcube/epdf.php?doi=10.1590/ S0102-311X2012000600006\&pid=S0102311X20120006 00006\&pdf_path $=\mathrm{csp} / \mathrm{v} 28 \mathrm{n} 6 / 06 . \mathrm{pdf}$

16. Ministério da Saúde (BR). Secretaria de Atenção à Saúde. Departamento de Ações Programáticas Estratégicas. Política nacional de atenção integral à saúde do homem: princípios e diretrizes. Brasília (DF): MS; 2008.

17. World Health Organization. Good health adds life to years: Global brief for World Health Day [Internet]. 2012 [cited 2015 Mar 09]; Available from: http://whqlibdoc.who.int/hq/2012/WHO_DCO_ WHD_2012.1_eng.pdf

18. Ministério da Saúde (BR). Secretaria de Atenção à Saúde. Departamento de Ações Programáticas Estratégicas. Departamento de Ações Programáticas Estratégicas. Política nacional de atenção integral à saúde da mulher: princípios e diretrizes. Brasília (DF): MS; 2011.

19. Bocchi EA, Marcondes-Braga FG, Bacal F, Ferraz AS, Albuquerque D, Rodrigues D, et al. Sociedade Brasileira de Cardiologia. Atualização da Diretriz 
Brasileira de Insuficiência Cardíaca Crônica - 2012. Arq Bras Cardiol 2012: 98(1 supl. 1): 1-33

20. Santos VCF, Kalsing A, Ruiz ENF, Roese A, Gerhardt TE. Perfil das internações por doenças crônicas não transmissíveis sensíveis à atenção primária em idosos da metadeSul do RS. Rev Gaúcha Enferm. 2013;34(3):124-31.

21. Bento VFR, Brofman PRS. Impacto da consulta de enfermagem na frequência de internações em pacientes com insuficiência cardíaca em Curitiba Paraná. Arq Bras Cardiol. 2009 Jun; 92(6):490-6.

22. Neto FRGX, Sampaio JJC. Processo de ascensão ao cargo e as facilidades e dificuldades no gerenciamento do território na Estratégia Saúde da Família. Rev Bras Enferm. 2008; 61(1):36-45.
23. Ministério da Saúde (BR). Secretaria de Assistência à Saúde. Coordenação de Saúde da Comunidade. Saúde da Família: uma estratégia para a reorientação do modelo assistencial [Internet]. Brasília (DF): MS; 1997 [cited 2016 Set 28]. Available from: http:/ / bvsms. saude.gov.br/bvs/publicacoes/cd09_16.pdf

24. Rehem TCMSB, Ciosak SI, Egry EY. Ambulatory care sensitive conditions: general hospital of microregion of São Paulo municipality, Brazil. Texto Contexto Enferm [Internet]. 2012 [cited 2015 Jul 27]; 21(3):535-42. Available from: http://www. scielo.br/scielo.php?script=sci_arttext\&pid=S010407072012000300007\&lng=en 